\title{
Study to Assess the Level of Stress among Nursing students
}

\author{
Mandeep Kaur ${ }^{1}$, Kanika Guleria ${ }^{2}$, Anisha ${ }^{3}$ \\ ${ }^{1}$ Nursing Tutor, Chitkara School of Health Sciences, Chitkara University, Punjab, India, ${ }^{2}$ Assistant Professor, \\ Chitkara School of Health Sciences, Chitkara University, Punjab, India, ${ }^{3}$ Nursing Tutor, Chitkara School of Health \\ Sciences, Chitkara University, Punjab, India
}

\begin{abstract}
Stress is a state created by amendment in atmosphere that is damaging to the person's equilibrium and is mostly prevalent in nursing students. The study aims to measure the stress level of nursing students. Sample size consisted of 63 nursing students of GNM $1^{\text {st }}$ year and B.Sc.(N) Post basic $1^{\text {st }}$ year chosen by convenience non-probability sampling technique and informed consent were taken from subjects. The UN Management stress tool was used to collect data which was taken from UNO Management Booklet of series. The results of the study has revealed that $97 \%$ of GNM $1^{\text {st }}$ year students and $67 \%$ of Post Basic B.Sc. Nursing students were in moderate stress. The stress level is high in GNM $1^{\text {st }}$ year students as compare to post basic BSc Nursing $1^{\text {st }}$ year. Mean stress score of Post Basic B.Sc.(N) $1^{\text {st }}$ year and GNM $1^{\text {st }}$ year was 17 $\pm 2.3 \& 23 \pm 3.5$.
\end{abstract}

Keywords: Prevalence, Stress, Nursing Students.

\section{Introduction}

Stress is produced by varying environment. It disturbs the mental balance of any person. Nursing is training is one of the most stressing training. Numerous studies have shown that there are many reasons of stress throughout nursing training. The prevalent sources of stress felt by students and faculty that comprises curriculum requirements, assignments and examinations and combining clinical work with studies. ${ }^{1}$

According to the Oxford University, it is a state of affair involving on physical or mental energy. We can define stress as private state that is produced by physical requirements on the body or by atmosphere and social state of affairs that are evaluated as probably harmful, not under control or surpassing our resources for coping. Seyle has defined stress as excessive burning of energy resources.

\footnotetext{
Corresponding Author:

Ms. Mandeep Kaur

Chitkara School of Health Sciences, Chitkara

University, Punjab

Contact No.: 9878580276

e-mail: mandeep.kaur.n@chitkara.edu.in
}

Stress is a big problem in the society. $75 \%$ of bodily disease are said to be due to stress. There are many stressors like transitions in life, money problems, pressure of day-to-day life, no leisure time, problems in relationships and domestic problems. Nursing students face both academic as well as professional stress during their training period. ${ }^{2}$ Academic stress is that stress which is faced by students during academic period. One study suggested that stress is linked with the type of institution in which the nursing student studies. For instance, Curriculum pattern of private college can be different from Government nursing College. ${ }^{3}$ Professional stress is that which is caused during job.

\section{According to "UN Management Booklet" stress is of three types:}

1. Basic stress: It is a minor stress which include in day-to-day situation that tension, frustration, anger \& irritation.

2. Cumulative stress: It is a result of strain occurs too often, more severe and stays for longer period.

3. Traumatic stress: This stress threatens physically or psychologically.

Stress can have a positive and negative aspect, when it is positive it acts as motivator for growth but when it 
is negative, it causes illness. Academic stress becomes serious mental health problem. Nursing students are important and beneficial human assists. Detection ofstress is extremely important as it can be the reason of low productivity, decreased quality of life and suicidal thoughts which are due to examination, assignments submission, and assessment.

According to study done on nursing students in public university, more than $50 \%$ subjects had stress symptoms. This stress decreases quality of life of students. ${ }^{4}$

The study conducted on 455 nursing students in Nursing college, Brazil revealed that $64 \%$ of students were having stress ${ }^{5}$.

Study done at PGIMER Chandigarh on 43 Nursing students, revealed that the moderate stress level was 99.2 among 5 students, mild stress 72.33 among 21 students and no stress is 46.42 among 17 students. $11.62 \%$ subjects experienced moderate stress and $48.83 \%$ experienced mild stress, $39.53 \%$ experienced no stress. ${ }^{6}$

According to, one more study done at Seth Medical College to assess level of stress among medical students. Results of their study has shown that majority of students perceived $73 \%$ stress and high stress level was stress found in $2^{\text {nd }}$ year rather in $1^{\text {st }}$ or $3^{\text {rd }}$ year. ${ }^{7}$

In the present scenario, stress has become a big problem especially among students. This condition can be witnessed among nursing students, so researcher has conducted a study to find out the stress level of nursing students of Nursing college of Punjab.

\section{Subjects and Method}

A descriptive research design was adopted for the study. Study was conducted at Kular College of Nursing, Kishangarh. The sample of 63 students was chosen by convenience sampling technique. All the nursing students who were ready to give informed consent were included in the study. Those who didnot give informed consent or who were not accessible at the time of compilation of data were excluded from the study. This study was approved by Advisory Committee of Nursing College and participants were included in the study after taking permission from Principal of College and students were assured of confidentiality. A structured Performa containing socio demographic data including the basic information such as age, sex, marital status, nursing course, subjects was distributed to the participants. A standard questionnaire tool was taken from UNO Management of Stress Management: In this tool, 10 questions were given to assess stress and it had maximum score of 30 and minimum score of 15 . Score upto 15 considered normal, 15 - 25 considered Moderate Stress level and $25-30$ considered Severe Stress level. The descriptive and inferential statistical measures used for analysis for identifying the result of study.

\section{Results}

Ninety-seven percent of the study population was Female and three percent were Male. Maximum respondents were from the rural background. $75 \%$ from rural area and $25 \%$ from urban area. Only $8 \%$ of subjects were married and rest $92 \%$ were unmarried. The subjects of 18 years of age or less than 18 years had more stress than subjects of morethan 18-years-of-age. (Table 1).

Table 1: Socio demographic variables of the subjects from both the groups. $N=63$

\begin{tabular}{|l|c|c|}
\hline Demographic Variables & N & \% \\
\hline Age & & \\
$<18$ or 18 & 20 & $32 \%$ \\
$19-22$ & 24 & $38 \%$ \\
23 or $>23$ & 19 & $30 \%$ \\
\hline Marital status & & \\
Married & 6 & $8 \%$ \\
Unmarried & 57 & $92 \%$ \\
\hline Sex & 2 & \\
Male & 61 & $97 \%$ \\
Female & & \\
\hline Resident & 47 & $75 \%$ \\
Rural & 16 & $25 \%$ \\
Urban & & \\
\hline Classes & 36 & $57 \%$ \\
GNM & 27 & $43 \%$ \\
Post Basic B.Sc.(N) & & \\
\hline
\end{tabular}

Table 1 depicted that, more than half of the subjects (38\%) were from age group of 19-22. Majority of the females $(97 \%)$ were unmarried (92\%). Majority of the subjects $(75 \%)$ were from rural area. More than half of the subjects (57\%) were from GNM $1^{\text {st }}$ year. 
Table 2: Mean score of stress levels among GNM $1^{\text {st }}$ year and B.Sc (N) Post basic $1^{\text {st }}$ year students

\begin{tabular}{|l|c|c|}
\hline Classes & GNM 1 $1^{\text {st }}$ year & $\begin{array}{c}\text { Post Basic B.Sc. } \\
\text { Nursing 1 } \text { 1s }^{\text {year }}\end{array}$ \\
\hline Mild stress & $1(3 \%)$ & $9(33 \%)$ \\
\hline Moderate stress & $35(97 \%)$ & $18(67 \%)$ \\
\hline Mean \pm SD & $23 \pm 3.5$ & $17 \pm 2.3$ \\
\hline
\end{tabular}

Table 2 depicted that moderate stress (97\%) was more in GNM $1^{\text {st }}$ year students and rest of the subjects had mild stress with a mean score of $23 \pm 3.5$ whereas in B.Sc (N) Post Basic 1st Year, more than half of subjects $(67 \%)$ had moderate stress and rest of the subjects had

mild stress with a mean score $17 \pm 2.3$. The G.N.M $1^{\text {st }}$ year subjects were having more stress than B.Sc. (N) Post Basic 1st Year as indicated by the higher mean score.

Prevalence of Stress: About $97 \%$ GNM $1^{\text {st }}$ year students and $67 \%$ B.Sc (N) Post basic $1^{\text {st }}$ year students had Moderate stress level. Mean stress score of GNM $1^{\text {st }}$ year students came out $23 \pm 3.5$ and Mean stress score of Post basic 1st year students was $17 \pm 2.3$. The finding shows that the level of moderate stress is higher than mild stress $\&$ there is no case of severe stress. (Table 2 \& Figure 1).

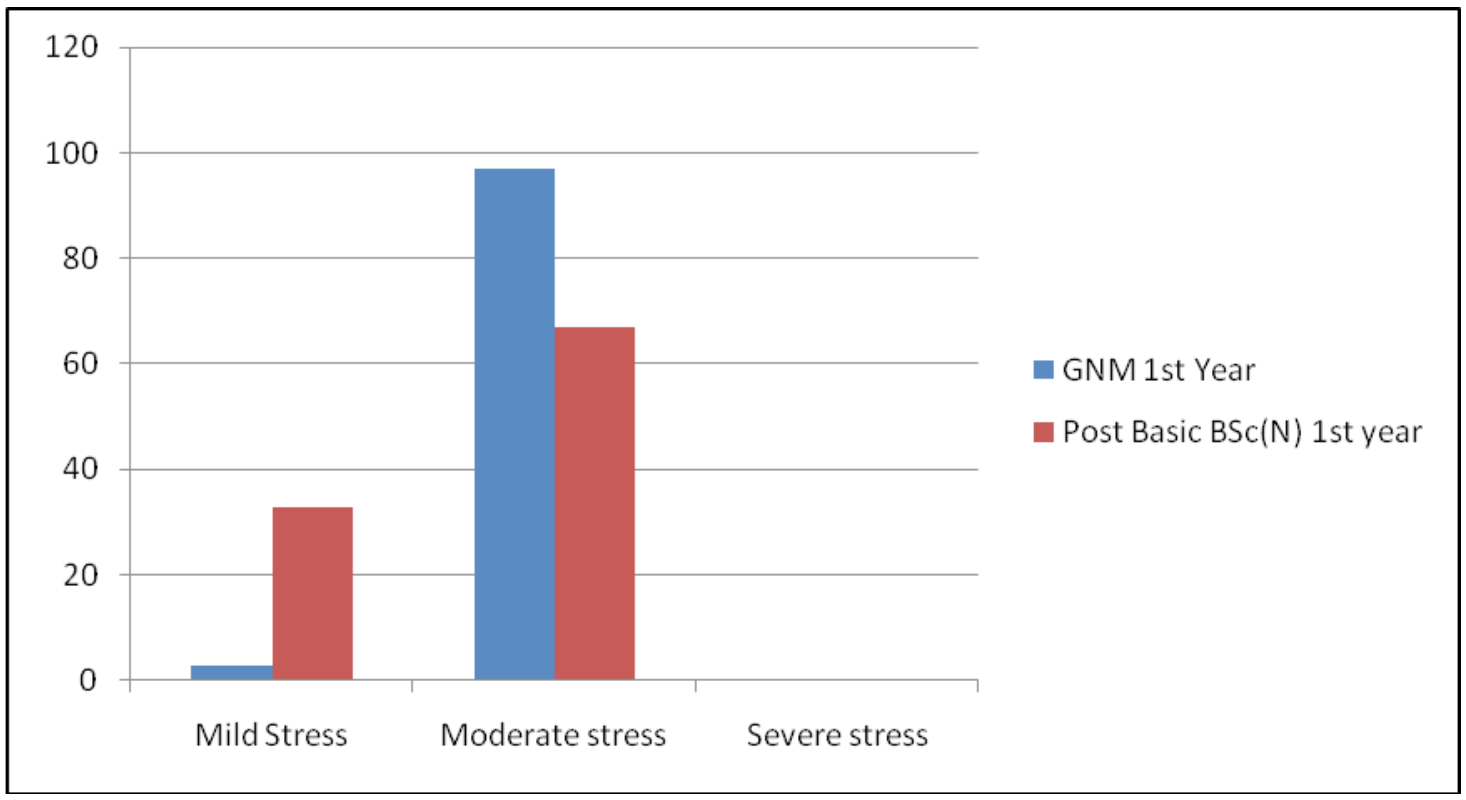

Figure 1: Percentage distribution of stress level among both groups.

Figure 1 depicts that $97 \%$ subjects of GNM $1^{\text {st }}$ year and $67 \%$ subjects of Post basic B.Sc.(N) $1^{\text {st }}$ year had moderate stress. And 3\% subjects of GNM $1^{\text {st }}$ year and $33 \%$ of Post Basic BSc (N) $1^{\text {st }}$ year had mild stress. None of the subjects has severe stress.

Table 3: Association between stress scores and selected demographic variables.

\begin{tabular}{|l|c|c|c|c|c|c|}
\hline Demographic variables & Mild stress & Moderate stress & df & Table value & Chi square & p-value \\
\hline Age & & & & & \\
$<18$ or 18 & 1 & 19 & 2 & 5.99 & $5.3536^{\mathrm{S}}$ \\
$19-22$ & 7 & 17 & 17 & & & \\
23 or $>23$ & 2 & 2 & 1 & 3.84 & $12.812^{\mathrm{s}}$ & 0.0687 \\
\hline Marital status & 4 & 51 & & & \\
Married & 6 & & & & \\
Unmarried & & & & & & \\
\hline
\end{tabular}




\begin{tabular}{|l|c|c|c|c|c|c|}
\hline Demographic variables & Mild stress & Moderate stress & df & Table value & Chi square & p-value \\
\hline Sex & 1 & 1 & 1 & & & \\
Male & 9 & 52 & 1 & 3.84 & $1.8015^{\mathrm{NS}}$ & 0.1794 \\
Female & 9 & 38 & 1 & 3.84 & $1.4873^{\mathrm{NS}}$ & 0.2226 \\
\hline Resident & 1 & 15 & 1 & & & \\
Rural & 1 & 35 & 1 & 3.84 & $10.7873^{\mathrm{S}}$ & 0.0009 \\
Urban & 9 & 18 & & & & \\
\hline Classes & 1 & & & & & \\
GNM & & & & & & \\
Post Basic B.Sc.(N) & &
\end{tabular}

Table 3 shows that the association between stress scores and socio demographic variable such as age, marital status and classes found significant, as calculated value is greater than tabulated value at the $\mathrm{p}$ level of significance $<0.05$. It means stress scores were associated with age and marital status. And the association between stress scores and socio demographic variables such as sex and gender found non-significant, as calculated value is less than tabulated value at the $p$ level of significance $<0.05$.

\section{Discussion}

The present study showed that level of moderate stress was higher than mild stress. The level of moderate stress among 35 students of GNM $1^{\text {St }}$ year was $97 \%$ percentage and $67 \%$ among 18 students of B.Sc (N) Post basic $1^{\text {st }}$ year. According to one study conducted among nursing students in Kathmandu university to assess the academic stress, the result came out with $75 \%$ students with academic stress ${ }^{[8]}$.Similar result was found in one study done on Nursing workers. It was a comparative study to determine job related stress, stress reaction, coping strategies adopted by nursing personnel working in critical and non-critical unit of selected hospital of Delhi. It was found that percentage of moderate stress was higher that is $59.65 \%$ than mild stress $22.81 \%$. Most of them felt troubles in participation in social life due to institute's timings, living away from home, lack of time for self- study, strict rules and regulation in the hospital, unable to get leisure time for recreation. The finding of the research showed that the moderate stress was more in the age group of 18 or less than $18(95 \%)$ as compare to other age group. Similar result was found in one study done on nursing students of B.Sc Nursing $1^{\text {st }}$ year at PGI Chandigarh. The results of the study has shown that the stress level was greater in the age group of $17-22$ years
\& level of moderate stress was higher than mild stress. Mean of moderate stress is $99.2 \& 72.33$ in mild stress.

\section{Conclusion}

Stress has become a never ending, continuous \& prevalent condition in today's world. Preset generation is marked as generation of stress. Everyone experiences various forms of stress in their lives. Stress has become very common among the students. In the present research, attempt was made to determine the stress among nursing students in Nursing College, Punjab following a descriptive design. This study has tried to assess the mental well-being or the lack thereof, of the students undergoing nursing training. The fact that these students are finding the subjects difficult, living in hostels, doing shift duties in hospitals, academic workload is reflected in the significantly higher incidence of stress that they experience, as compared to the general population. We suggest that an induction program at the start of the nursing course, and positive mental health training can go a long way toward reducing strain of nursing students and can provide betterment to their professional and personal well-being.

Acknowledgement: The researchers would like to express their special thanks to Mrs Aditya Sharma, Former Principal of Kular College of Nursing for permitting us to perform the study and all the participants of this study for their valuable responses.

\section{Financial Support \& Sponsorship: Nil}

Conflict of Interest: There are no conflict of interest

Ethical Clearance: Taken from the ethical and research committee of Kular College of Nursing. 


\section{References}

1. Labrague LJ. Stress, stressors, and stress responses of student nurses in a government nursing school. Heal Sci J. 2013;7(4):424-35.

2. Pulido-Martos M, Augusto-Landa J-M, LopezZafra E. Sources of stress in nursing students: a systematic review of quantitative studies. Int Nurs Rev [Internet]. 2012;59(1):15-25. Available from: http://www.scopus.com/ inward/record.url?eid=2-s2.0-84857037280 \& partnerID $=$ tZOtx $3 y 1$

3. Sharma N, Kaur A. Factors associated with stress among nursing students. Nurs Midwifery Res J. 2011;7(1):12-21.

4. Mota NIF, Alves ERP, Leite GDO, Sousa BSMA de, Ferreira Filha M de O, Dias MD. Estresse entre graduandos de enfermagem de umauniversidadepública. SMAD Rev EletrônicaSaúdeMentÁlcool e Drog (Ediçãoem Port [Internet]. 2016;12(3):163. Available from: http:// www.revistas.usp.br/smad/article/view/120787
5. Ribeiro V, Cestari F, Barbosa IV, Sampaio Florêncio R, Lúcia V, De M, et al. Stress in nursing students: study on sociodemographic and academic vulnerabilities. Acta Paul Enferm Acta Paul Enferm. 2017;30(302):190-6190.

6. Dhar R, Walia I, Das K. Descriptive study to assess the causes of stress and coping strategies used by the newly admitted bascic BSc Nursing students. 2009;(1):31-7.

7. Supe AN. A study of stress in medical students at Seth G.S. Medical College, J Postgrad Med [Internet]. 1998;44(1):1-6. Available from: http:// www.jpgmonline.com/article.asp?issn $=0022$ 3859 ; year $=1998 ;$ volume $=44 ;$ is sue $=1 ; \mathrm{s}$ page $=1$;epage $=6$; aulast $=$ Supe

8. Acharya Pandey R, Chalise HN. Self-Esteem and Academic Stress among Nursing Students. Kathmandu Univ Med J (KUMJ) [Internet]. 2015;13(52):298-302. Available from: http:// ovidsp.ovid.com/ovidweb.cgi?T=JS \& PAGE $=$ reference \& $\mathrm{D}=$ prem \& NEWS $=\mathrm{N} \quad \&$ $\mathrm{AN}=27423$ 